\title{
APPROXIMATE DETERMINATION OF THE CELL-WALL COMPLEX OF VEGETABLES BY ENZYMATIC DIGESTION
}

\author{
Majja-Lissa Salo \& Kaija Kotilainen \\ Department of Animal Husbandry, University of Helsinki
}

Received January 13, 1967

In a previous publication SALO (1965) presented an analysis method in which the carbohydrates in foods were determined as groups and different sugar anhydrides were determined from heterogeneous groups. In this way, for example the digestibility of different kinds of carbohydrates can be established in digestibility trials. However, for many practical purposes this kind of fractination is unnecessarily complicated. A division into two groups would be sufficient: one group would consist of the carbohydrates which are hydrolysed by the digestive juices, namely sugars, fructosan and starch. The second group would consist of those carbohydrates which are decomposed only by microbial action, i.e. hemicellulose and cellulose. The latter group could in many cases also include lignin.

Apparently the purpose of the Weende crude fibre determination was originally to establish the cell-wall carbohydrates + lignin complex, although it soon became evident that generally only a small part of the hemicellulose and lignin remained in the fibre. Likewise, in the membrane substance determination of PALOHEIMO and Paloheimo (1949), and especially in the normal-acid fibre determination of Walker and Hepburn (1955), Jones and Griffith (1962), Griffith and Jones (1963) a part of the hemicellulose is dissolved. In the studies carried out by RUBNER (1916a, 1916b, 1919) at the beginning of this century, on the other hand, results approximating rather closely the total amounts of cell-wall material were achieved, the methods are very complex for routine work, however. The procedure of PALOHEIмO and VAINIO (1965), requiring different correction determinations, is also laborious, even though it gives a rather accurate determination of the complex of cell-wall substances in animal foods.

The purpose of the present investigation was to find out whether by treating vegetables with proteolytic enzymes it is possible to obtain a residue which roughly corresponds to the cell-wall complex. In starch-containing material, diastase would 
also be used in the treatment. From the carbohydrate investigations of SALo (1965, p. 44) it was known that the hemicellulose in vegetables is readily soluble. Thus it could be assumed that if the major part of the protein in the sample dissolved, a part of the hemicellulose would also dissolve. Since a protein correction was not desired in the procedure, it was decided to investigate which extraction method would be most successful in dissolving as much protein as possible and only a little of the hemicellulose, and further, whether the amounts of dissolved hemicellulose and protein remaining in the residue were approximately equal in magnitude.

\section{Materials}

The experimental material consisted of 12 different kinds of vegetables whose detailed analytical data are given in a separate paper (SALO 1967). The samples were dryed in a vacuum oven at $40^{\circ}$ and ground using a sieve No. $40(0.42 \mathrm{~mm})$.

\section{Methods and results}

As the basis of the method, the proteolytic enzymes pepsin, trypsin and papain were employed, for starch-containing materials diastase was added. Comparisons were made with the sum hemicellulose + cellulose + lignin (SALO 1967). The main points to be investigated were the preliminary extraction, as well as the suitable $\mathrm{pH}$ and temperature for the enzyme digestion. Not only was the quantity of the insoluble residue determined but also its protein and ash contents. The ash content can give indications of the solubility of organic acid salts and the adequacy of washing.

Several alternative methods were tried observations on which are given later in this paper. The methods judged to be best consisted of preliminary extraction of the sample with $85 \%$ ethanol and subsequent enzyme treatment with pepsin, trypsin, or trypsin + diastase at $40^{\circ}$. In the pepsin treatment the solution

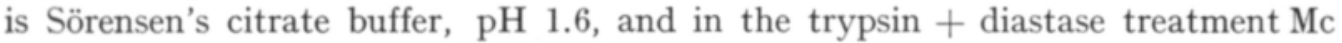
Ilvaine's citric acid + phosphate buffer, $\mathrm{pH}$ 7.2.

Pr o c e d u re. One gram of the ground sample is weighed into folded filter paper and extracted with $85 \%$ ethanol for $5 \frac{1}{2}$ hours in a Soxhlet apparatus. The residue is allowed to dry at room temperature and is then transferred to a $100-\mathrm{ml}$ Erlenmeyer flask. The necessary buffer solution is prepared and into this is dissolved either $0.2 \%$ pepsin (Merck 1: 3500 ) or $0.2 \%$ trypsin (Merck 20000). In the trypsin experiments a small amount of thymol is added at this stage. At first only a small volume of the solution is put in the flask. After about 15 minutes, when possible lumps have become thoroughly moistened, they are crushed with a glass rod and the flask is filled almost to capacity. A rubber stopper is inserted and the flask is shaken. It is then held at $40^{\circ}$ and shaken occasionally during the first few hours. After 20 hours the solution is filtered through a dried and weighed folded filter paper (Whatman No. $1, \varnothing 11 \mathrm{~cm})$. It is washed several times with a small volume of water, the total not to exceed $100 \mathrm{ml}$. The filter papers with their residues are placed in the same 
weighing dishes where they were originally dried, and the drying is carried out in a vacuum oven at $70^{\circ}$ for 24 hours after which the samples are weighed.

If the sample contains starch, $0.2 \%$ diastase (Merck, hochgereinigt) is added to the trypsin solution. In such cases the extracted sample is first boiled in $20 \mathrm{ml}$ water for 10 minutes and then cooled. The filtered enzyme solution is added and the procedure is continued as described above.

Results. The analysis results are shown in Table 1 . In addition to the total amount of insoluble residue, the table also gives the protein and ash contents of the residue as well as a comparison of the results with the sum of hemicellulose, cellulose and lignin.

The table shows that results satisfactorily approaching the purpose of the study, i.e. the sum of cell-wall substances, are obtained only for some of the vegetables. In most cases the residue does not consist merely of carbohydrates and lignin, as does the comparison value, but also contains considerable quantities of protein and, in some of the vegetables, ash. The hemicellulose has dissolved in amounts of $3-10 \%$ of the original dry matter, which corresponds to $20-55 \%$ of the total hemicellulose. Lower percentage figures occur in the Brassica species and spinach, higher ones in cucumber, onion and lettuce. The differences in solubility are scarcely explained by the composition of the cell wall (SALO 1967). Galactans and arabans, the most readily soluble polysaccharides of the cell wall, make up a very large part of the hemicellulose in all the vegetables. Lettuce contains exceptionally large amounts of uronic anhydrides. It is likewise not possible to predict the solubility of hemicellulose on the basis of the cellulose and lignin contents. The quantities of protein remaining in the residue are greater in materials with a high protein content.

Table 1. The residues after digestion with proteolytic and amylolytic enzymes. Unless otherwise stated the figures are percentages of dry matter.

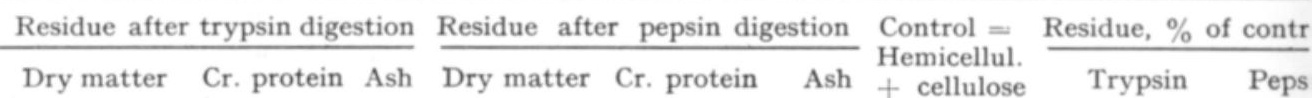
+ lignin

\begin{tabular}{|c|c|c|c|c|c|c|c|c|}
\hline Red beet & 17.5 & 0.7 & 1.1 & 16.0 & 1.2 & 0.1 & 21.4 & 82 \\
\hline Onion, red & 10.7 & 0.3 & 0.8 & 10.3 & 0.5 & 0.1 & 14.7 & 73 \\
\hline Tomato & 20.6 & 1.6 & 1.2 & 21.4 & 1.9 & 0.2 & 21.7 & 95 \\
\hline Cucumber, green & 15.7 & 1.2 & 1.5 & 15.0 & 1.2 & 0.2 & 18.9 & 83 \\
\hline Lettuce & 27.9 & 3.6 & 2.4 & 28.7 & 4.9 & 0.7 & 31.6 & 88 \\
\hline Spinach, New Zealand & 28.4 & 3.9 & 2.0 & 27.9 & 3.7 & 1.8 & 26.1 & 109 \\
\hline Cauliflower & 30.7 & 3.6 & 1.6 & 29.3 & 3.8 & 0.4 & 29.5 & 104 \\
\hline Broccoli & 32.8 & 3.3 & 1.7 & 32.3 & 4.4 & 0.4 & 31.7 & 103 \\
\hline Cabbage, white & 24.9 & 1.0 & 1.6 & 23.8 & 1.6 & 0.2 & 25.6 & 97 \\
\hline Swede & 24.9 & 0.7 & 1.6 & 25.1 & 1.2 & 0.1 & 25.0 & 100 \\
\hline Carrot & $\left.23.0^{1}\right)$ & 0.9 & 1.3 & 28.6 & 1.4 & 0.2 & 26.6 & $\left.86^{1}\right)$ \\
\hline Bean, green & $\left.30.8^{1}\right)$ & 5.4 & 1.6 & 43.6 & 2.9 & 0.5 & 27.2 & $\left.113^{1}\right)$ \\
\hline
\end{tabular}

1) trypsin + diastase 
The pepsin treatment is not suited for starch-containing vegetables. These must be treated with a mixture of trypsin and diastase. Of the vegetables listed in Table 1, carrot and bean were treated with the trypsin + diastase solution. Starch granules are entirely decomposed in this treatment.

Performance of the analyses is easy and rapid; there can be $10-12$ samples in the same series.

Other experimental results and observations. In trying out various alternative methods, the following observations were made:

Preliminary extraction is necessary, especially for the sake of filtration, and ethanol is a suitable solvent for this purpose. Ethanol-benzene (1:2) is satisfactory for some of the vegetables, bur for others the filtration is just as slow as without extraction. A consequence of slow filtration is inadequate washing, in which e.g. salts of the buffer solutions remain in the residue.

$0.1 \mathrm{~N} \mathrm{HCl}$ at $40^{\circ}$ dissolves large quantities of hemicellulose in all the vegetables, a fact which was already known from previous experiments (SALO 1965, p. 44). In such an acidic solution, pepsin effectively dissolves protein.

Even $0.01 \mathrm{~N} \mathrm{HCl}$ dissolves some hemicellulose in vegetables. In some of the vegetables pepsin effectively dissolves protein also in this solution, but in many plant materials so much alkaline matter is dissolved that the $\mathrm{pH}$ of the solution may rise from the initial $\mathrm{pH} 2$ to more than $\mathrm{pH} 3.5$. Since the activity of pepsin decreases considerably even around $\mathrm{pH} 2.5-3$, Sörensen's citrate buffer $(\mathrm{pH} 1.6)$ was used, as a result of which the $\mathrm{pH}$ stayed within the range 1.7-1.9. In this solution pepsin decomposes protein nearly as well as in the $0.1 \mathrm{~N} \mathrm{HCl}$ solution $(\mathrm{pH} 1)$ while at the same time it dissolves considerably less hemicellulose than in the latter solution.

Trypsin was first tested in distilled water. The result was the same as for pepsin in $0.01 \mathrm{~N} \mathrm{HCl}$ : in some of the vegetables the $\mathrm{pH}$ changed, in this case decreased, so much that the decomposition of the protein was weakened and filtration was delayed. A suitable buffer was Mc Ilvaine's citric acid + phosphate buffer, pH 7.2. The vegetables caused virtually no change in the $\mathrm{pH}$ of this solution.

Papain was tried in the same kind of buffer solution and $\mathrm{pH}$ as trypsin. Experiments were made with only a few samples, since papain proved to be more difficult to handle than the other two enzymes. The commercial papain preparation employed contains some insoluble additive. The results were nevertheless about the same as in the trypsin treament.

Since unexpectedly large amounts of hemicellulose dissolved from the vegetable materials in the $40^{\circ}$ treaments, experiments were made with trypsin and papain at room temperature, using onion and broccoli as test materials. The time of enzymatic treatment was $20-70$ hours. It was found that at such a low temperature the activity of both enzymes is considerably decreased. The amount of protein remaining in the residue was nearly three times as great as in the treatment at $40^{\circ}$. Some hemicellulose dissolved even at room temperature, especially in onion, while the same occurred with a simple aqueous extraction at room temperature. The use of thymol and toluene in small quantities did not appear to depress the activity of the enzymes. 
Table 2. The residues after ethanol extraction. The figures show percentages of dry matter.

\begin{tabular}{|c|c|c|c|c|c|c|}
\hline & \multicolumn{3}{|c|}{ In $60 \%$ ethanol-insoluble } & \multicolumn{3}{|c|}{ In $80 \%$ ethanol-insoluble } \\
\hline & $\begin{array}{c}\text { Dry } \\
\text { matter }\end{array}$ & $\begin{array}{c}\mathrm{Cr} . \\
\text { protein }\end{array}$ & Ash & $\begin{array}{c}\text { Dry } \\
\text { matter }\end{array}$ & $\begin{array}{c}\mathrm{Cr} . \\
\text { protein }\end{array}$ & Ash \\
\hline Onion & 15.2 & 2.1 & 0.8 & 17.3 & 2.7 & 1.3 \\
\hline Lettuce & 49.2 & 18.7 & 4.1 & 54.1 & 20.1 & 6.3 \\
\hline Spinach & 49.1 & 18.9 & 3.5 & 65.4 & 20.7 & 12.7 \\
\hline Cauliflower & 46.0 & 16.6 & 2.0 & 50.8 & 17.8 & 3.7 \\
\hline Carrot & 34.6 & 4.0 & 1.8 & 39.9 & 4.5 & 2.8 \\
\hline
\end{tabular}

The effect of mere boiling in ethanol was likewise studied. The solvent was either a $60 \%$ or $80 \%(\mathrm{v} / \mathrm{v})$ aqueous solution of ethanol and the time of boiling was two hours. Examples of the solubility of different kinds of vegetables during such treatment are given in Table 2 . The residue contains, as expected, more protein and ash than the residue after enzyme treatment, moreover it also has starch and some salts of organic acids. An additional experiment made with the organic acid salts showed that Ca-oxalate and Ca-citrate do not dissolve in $80 \%$ nor in $60 \%$ ethanol. The corresponding $\mathrm{K}$ and $\mathrm{Na}$ salts of these acids dissolve in $60 \%$ but not in $80 \%$ ethanol, a fact which explains the differences in the ash content of the residues. In the pepsin and trypsin treatments the $\mathrm{K}$ and $\mathrm{Na}$ salts dissolve but the Ca-oxalate is insoluble; moreover, the Ca-citrate remained undissolved in the trypsin treament.

If mere boiling in ethanol were to be taken as the basis for determining the cell-wall complex, the method would have to comprise several correction determinations. Furthermore, the ethanol solution would have to be especially strong. In the case of many vegetables, it is observed that the corrected results are smaller than the sum of the cell-wall carbohydrates and lignin, which is used as control. This is evidently due to the solution of some of the cell-wall polysaccharides or other sugar anhydride-containing compounds in $60-80 \%$ boiling ethanol (SALO, 1965 p. 53). The determinations for the control values were made from samples which were untreated for determining the uronic anhydrides and extracted in about $90 \%$ ethanol for determining the other cell-wall carbohydrates. The value as regards uronic anhydrides is thus slightly too high for comparison.

\section{Sum mary}

The paper describes the results of experiments in which 12 different vegetables were treated with pepsin, trypsin or trypsin + diastase in buffer solutions. The effects of certain variations in the methods on the final results are also discussed. The purpose of the study was to find out whether it would be possible to develop a simple procedure that would yield a residue roughly corresponding to the cell- 
wall complex in readily soluble plant materials such as vegetables. However, such great differences were found in the solubility of hemicellulose and protein among the different materials that good results cannot be achieved by a uniform method, at least not without many correction determinations.

\title{
REFERENCES
}

Griffith, G. \& Jones, D. I. H. 1963. The normal-acid method for the determination of fibre in roughages. J. Sci. Food Agric. 14: 380-385.

Jones, D. I. H. \& Griffith, G. 1962. Normal-acid fibre method for evaluating roughages. Nature 193: $882-883$.

Paloheimo, L. \& Paloheimo, I. 1949. On the estimation of the total of vegetable membrane substances. J. Sci. Agric. Soc. Finl. 21: 1-16.

Palohermo, L. \& VAinio, K. A. 1965. Determination of the complex of cell wall substances in plant products. Ibid. 37: $305-312$.

Rubner, M. 1916a. Untersuchungen über die Zusammensetzung einiger Wurzelgewächse. Arch. Physiol. 1915 , p. $193-239$.

- 1916b. Uber die Verdaulichkeit der Zellmembranen des Spinates. Ibid. 1915, p. 259-266.

- 1919. Die Verdaulichkeit der Vegetabilien. Ibid. 1918, p. 63-66, 117.

Salo, M.-L. 1965. Determination of carbohydrate fractions in animal foods and faeces. Acta Agr. Fenn. 105: $1-102$.

-1967 . Carbohydrates of some vegetables. Ibid. 109: 101-104.

WALKER, D. M. \& HEPBURN, W. R. 1955. The analysis of roughages by the normal-acid fibre method, and its use for predicting the digestibility of roughages by sheep. Agric. Progr. 30: $118-119$.

\section{SELOST US:}

\section{SOLUNSEINÄMÄAINEKSEN LIKIMÄÄRÅISESTÄ MÄÄRITTÄMISESTÄ KASVIKSISTA ENTSYYMIKÄSITTELYILLÄ}

\author{
Maija-Lissa Salo ja Kaija Kotilainen \\ Yliopiston kotieläintieteen laitos, Helsinki
}

Kirjoituksessa esitetään tuloksia 12 erilaisen kasviksen suhtautumisesta puskuriliuoksessa suoritettuun pepsiini-, trypsiini- tai trypsiini-diastaasikäsittelyyn ja menetelmän eräiden yksityiskohtien vaikutuksesta lopputulokseen. Tarkoituksena oli kokeilla, onko mahdollista kehittää vähätöinen jäännösmenetelmä, jolla saataisiin karkeasti määritetyksi kasvisten kaltaisesta helppoliukoisesta kasvimateriaalista solunseinämäkompleksia vastaava jäännös. Hemiselluloosan ja proteiinien liukoisuudessa todettiin eri kasviksilla kuitenkin niin suuria eroavuuksia, että hyvään tulokseen ei yhtenäisellä jäännösmenetelmällä päästä ainakaan ilman monia korjausmäärityksiä. 